\title{
Osteoporose - risikofaktor eller sykdom? Definisjon, utbredelse, årsaker, diagnostisering og forebyggende tiltak
}

\author{
Anne Johanne Søgaard \\ Senter for forebyggende medisin, Ullevål sykehus \\ Korrespondanse: Institutt for allmennmedisin og samfunnsmedisinske fag, Seksjon for epidemiologi, Postboks 1130 Blindern, 0318 Oslo \\ Telefon: 22850649 Telefax: 22850620 E-post: a.j.sogaard@samfunnsmed.uio.no
}

\begin{abstract}
SAMMENDRAG
Vi vet foreløpig lite om utbredelsen av osteoporose i Norge - dvs. bentetthet (BMD) minst 2,5 standardavvik under gjennomsnittet for unge kvinner. Vi vet heller ikke om det har vært noen økning de siste 10-årene. Denne artikkelen gir en oversikten over emnet osteoporose - med vekt på risikofaktorer og forebyggende tiltak, og drøfter WHOs definisjon av osteoporose. I henhold til denne er osteoporose både en risikofaktor for brudd - $o g$ en betegnelse på en tilstand som forutsetter minst ett brudd (etablert osteoporose). Definisjonen innebærer at diagnosen osteoporose avhenger av det normalmaterialet man sammenliker med, og medfører at en meget stor andel av norske kvinner over 70 år vil få diagnosen osteoporose. En slik medikalisering vil kunne føre til hyppige legekontroller, angst og lavere fysisk aktivitet av redsel for å falle. Osteoporose er asymptomatisk før man har fătt brudd, og har ingen automatiske behandlingsmessige konsekvenser. Man kan likevel frykte at WHOs definisjon vil tvinge frem krav om medikamentell forebyggende behandling. Dette er problematisk fordi det er stor overlapping i bentetthet mellom de som får brudd og de som ikke får. Måling av BMD er imidlertid den beste metoden vi i dag har for å forutsi brudd - og er like god som blodtrykksmåling er til å forutsi slag. For å vurdere individuell risiko, bør imidlertid flere risikofaktorer for brudd kombineres. De viktigste risikofaktorene for lav bentetthet er: lav kroppsvekt/lav relativ vekt, vektreduksjon, lavt inntak av kalsium/D-vitamin, røyking, tidlig menopause, inaktivitet, høyt alkoholkonsum og genetiske faktorer. Tiltak med fokus på noen av disse har vist positiv effekt på BMD.
\end{abstract}

\section{Søgaard AJ. Osteoporosis - risk factor or disease? Definition, distribution, aetiology, diagnosis and prevention. Nor J Epidemiol 1999; 9 (2): 165-172.}

\section{ENGLISH SUMMARY}

At present we do not know the distribution of osteoporosis in the Norwegian population - i.e. bone mineral density (BMD) below 2.5 standard deviations of the mean of young females. Nor do we know whether or not there has been any increase in the prevalence of osteoporosis the last decades. This paper reviews research about osteoporosis - focusing on risk factors and preventive measures, and discusses the WHO definition of osteoporosis. Osteoporosis is, in accordance to this definition, both a risk factor for fracture and the notion of a condition which presuppose a fracture (established osteoporosis). The definition implies that the diagnosis of osteoporosis depend upon the material of reference we compare with, and entail that a large majority of women above 70 years of age will have osteoporosis. This medicalization may lead to more frequent visits to physicians for control, more anxiety and less frequent physical activity because of fear of falling. Osteoporosis does not cause pain or loss of function before a fracture has occurred, and the diagnosis is not meant to initiate therapy. Nevertheless we worry that the diagnosis may have its own momentum in that direction, and enforce demands for more medicine for the purpose of prevention. This is problematic because there is a large overlap in BMD between those who will have a future fracture - and those who will not. However, measuring BMD is the best single method to predict future fracture, and is just as good as a measure of blood pressure is to predict stroke. To assess individual risk, one should, however, use more than one fracture risk factor. The most important risk factors for low BMD are: low weight/low body mass index, weight reduction, low intake of calcium/vitamin-D, smoking, early menopause, inactivity, high alcohol consumption and genetic factors. Interventions focusing on some of these factors have been effective in increasing/not reducing BMD.

Mange hevder at osteoporose er blitt en moderne folkesykdom. Men hva er egentlig osteoporose? Vet vi hvor mange nordmenn som har osteoporose - og vet vi at det er mer osteoporose nå enn før? Hva vet vi om risikofaktorene, og hvordan kan vi forebygge osteoporose?

\section{DEFINISJONER}

Osteoporose kjennetegnes av forandringer i benstruktur og benmasse som fører til en endring av benets mekaniske styrke og dermed en økende risiko for brudd (Kanis et al., 1997). En langsom og gradvis 
reduksjon i benmasse, spesielt av corticalt ben, forekommer likt hos eldre menn og kvinner som ledd i den normale aldringsprossess (Type II). I tillegg er det hos kvinner et raskt innsettende tap av trabeculært ben relatert til fraværet av østrogen etter menopause (Type I) (European Commission, 1997).

Osteoporose defineres av WHO (WHO Study Group, 1994) som bentetthet (Bone Mineral Density = BMD) minst 2,5 standardavvik (SD) under bentetthetsgjennomsnittet for unge kvinner (T-score $-2,5$ eller lavere), mens diagnosen etablert osteoporose i tillegg krever et eller flere osteoporotiske brudd (SLK, 1997). Tilsvarende definisjoner finnes ikke for menn. Enkelte anbefaler å bruke de samme grenseverdier for BMD for menn som for kvinner (RCP, 1998), men det er ingen enighet om dette. WHOs definisjon betyr at ca. $30 \%$ av alle kvinner over 50 år vil være osteoporotiske. Dette samsvarer med en livstidsrisiko for brudd i underarm, rygg eller hofte hos en kaukasisk kvinne på ca. 30-40\% (Workshop, 1997; Kanis et al., 1997). WHOs definisjon betyr også at diagnosen osteoporose avhenger av det normalmaterialet man sammenliker med. I mange måleapparat er referansematerialet hentet fra målinger på ikke-skandinaver, med et annet gjennomsnitt enn norske menn og kvinner. Diagnosen "syk" vil m.a.o. være avhengig av hvilket referansemateriale man bruker. I tillegg avhenger andelen som får diagnosen osteoporose av om man måler BMD i rygg, underarm eller hofte (Falch og Meyer, 1998; Abrahamsen et al., 1997).

\section{OSTEOPOROSE SOM RISIKOFAKTOR}

Osteoporose gir ingen symptomer eller smerter før lidelsen eventuelt fører til brudd. Osteoporose - eller lav bentetthet, kan derfor betraktes som en risikofaktor for brudd i lårhals, ryggvirvel, håndledd/underarm, overarm, bekken og andre mindre hyppige lokalisasjoner blant voksne over 50 år. Slike brudd kalles ofte osteoporotiske brudd når de rammer eldre som resultat av et minimalt traume (Konsensus-rapport, 1996). Måling av bentetthet (BMD) er den beste metoden vi i dag har for å forutsi brudd - og er like god som blodtrykksmåling er til å forutsi slag og bedre enn kolesterolmålinger er til å forutsi hjerte/kar-sykdom (European Commission, 1997, Marshall et al., 1996). Akkurat som blodtrykkverdiene, er bentetthetsverdiene normalfordelt i en befolkning. Verdiene danner en kontinuerlig skala, og det finnes ingen verdi eller terskel som skiller de som vil brekke fra dem som unngår brudd (For oversikt: Kanis et al., 1997; Seeman, 1997). Det er best forutsigbarhet av brudd hvis bentettheten måles på samme sted som man forventer bruddet - f.eks. har måling av bentetthet $\mathrm{i}$ hofte best prediksjon for lårhalsbrudd.

Prospektive studier og meta-analyser viser at risikoen for lårhalsbrudd og andre osteoporotiske brudd øker med mellom $50 \%$ og $160 \%$ avhengig av type brudd/målested hvis benmassen reduseres med ett standardavvik (SD) (European Commission, 1997;
Marshall et al., 1996). Det mest vanlige er å regne med en fordobling av risikoen ved en reduksjon i BMD på 1 SD (RCP, 1998). En tilsvarende økt bentetthet (1 SD) er på den annen side forbundet med 30-50\% økt risiko for brystkreft (Cauley et al., 1996).

Lav bentetthet er for øvrig en selvstendig prediktor for død for personer over 70 år - bedre enn både blodtrykk og kolesterol (Johansson et al., 1998), selv om dødsårsaken neppe er lav bentetthet i seg selv.

Selv om bruddrisikoen øker med synkende bentetthet, er det viktig å være klar over at frakturrisikoen øker med alderen selv om bentettheten holdes konstant. Effekten av alder er sterkere enn effekten av bentetthet (Kanis et al., 1997).

\section{UTBREDELSE, OMFANG OG UTVIKLING AV OSTEOPOROSE}

Vi mangler befolkningsdata når det gjelder omfanget av osteoporose i den norske befolkning, men flere større befolkningsstudier av bentetthet (Tromsø, NordTrøndelag, Hordaland) er gjennomført og analysering pågår. Foreløpige tall fra Nord-Trøndelag (måling $\mathrm{i}$ underarm av et $5 \%$ utvalg av hele den voksne befolkning) viser at ca. $1 / 3$ av alle kvinner 50 år og eldre har osteoporose i følge WHOs definisjon, mens rundt 70\% av dem over 70 år har det samme (Siri Forsmo, personlig meddelelse). Foreløpige resultater fra undersøkelsen i Tromsø (måling i underarm av nær 8000 voksne individer) viser at maksimal bentetthet (peak bone mass $=$ PBM) var $25 \%$ høyere hos menn enn hos kvinner. Selv den laveste BMD-verdien for de eldste mennene lå over den høyeste $\mathrm{BMD}$-verdien (PBM) for kvinnene. Etter nådd PBM er nedgangen i BMD blant kvinner mer enn 25\% (Berntsen et al., 1996). Studier fra andre land viser at bentapet blant kvinner varierer fra 0 til 6\% per år, men at det normalt ligger på $0-2 \%$. Spesielt er bentapet stort fra ryggvirvlene de første årene etter menopausen. Generelt antas det at kvinner mister $35-50 \%$ av corticalt og trabekulært ben i løpet av livet (European Commission, 1997). Man er ikke enige om det finnes spesielle individer som kan karakteriseres som "fast losers" (European Commission, 1997). Prospektive studier tyder på at bentapet akselererer med alderen, heller enn å avta, slik det ser ut i tverrsnittsstudier (Seeman, 1997).

En undersøkelse av kvinner i Oslo (friske kvinner 50 år og over) viser at andelen med osteoporose varierer avhengig av målested. Målt $i$ lårhalsen hadde $14 \%$ osteoporose - målt i nedre ryggrad hadde $36 \%$ osteoporose (Falch og Meyer, 1998). Middelverdien for alle estimatene var $27 \%$ - dvs. at ca. 190000 norske kvinner har osteoporose (Konsensus-rapport, 1996).

$\mathrm{Vi}$ vet at bentetthet varierer fra land til land og mellom ulike distrikter i samme land. Beboere i Oslo ligger f.eks. blant de laveste i Europa - både for kvinner og menn målt både i ryggvirvler og lårhals. Forskjellen i bentetthet i ryggen mellom kvinner i Oslo og kvinner i land med høyest bentetthet tilsvarer nesten dobbelt så stor risiko for brudd hos Oslo-kvinnene 
(Falch og Meyer, 1998). En studie fra Oslo og Trondheim basert på kvinner som oppsøkte/ble henvist til bentetthetsmåling, tyder på at bentettheten i gjennomsnitt er lavere i Oslo-området (Høiseth, 1997).

Forskjellene i bentetthet mellom ulike steder i Norge og mellom land i Europa indikerer at årsaksfaktorene til lav bentetthet i stor grad er å finne i miljø- og livstilsfaktorer. Dette understrekes også i en Europeisk lårhalsbruddstudie (Johnell et al., 1995), som viste at over $50 \%$ av slike brudd kan tilskrives påvirkbare faktorer - slik som lav relativ kroppsvekt, fysisk inaktivitet, liten eksposisjon for sollys og lavt inntak av kalsium. På den annen side indikerer tvillingstudier at $60-80 \%$ av maksimal oppnådd benmasse er genetisk betinget (European Commission, 1997).

Det finnes ingen data som viser i hvilken grad bentettheten i den norske befolkningen er redusert/stabil/ $ø k t$ over tid. Data som viser økning i lårhalsbrudd de siste ti-årene, kan tyde på en nedgang i BMD, men dette vet vi lite om.

\section{ÅRSAKER TIL OSTEOPOROSE (PRIMAR OG SEKUNDAR OSTEOPOROSE)}

Det er vanskelig å skille risikofaktorer for lav bentetthet og risikofaktorer for brudd. Flere av de faktorene som omtales i det etterfølgende vil kunne virke på brudd gjennom lav bentetthet, men også direkte på brudd - gjennom redusert muskelstyrke, balanse, syn, generell svekkelse av allmenntilstanden m.m.

I tillegg til den normale reduksjon av bentetthet med alderen og med menopause for kvinner, finnes en rekke sykdommer og medisiner som bidrar til utvikling av osteoporose - f.eks. malabsorbsjonsykdommer, kronisk leversykdom, visse kreftformer, pasienter med pareser, reumatoid artritt, vedvarende amenorrhea hos kvinner i fertil alder, bruk av corticosteroider, heparinbehandling (se oversikter i Workshop, 1997; SLK, 1997). Dette kalles sekundær osteoporose.

Det er beskrevet en rekke risikofaktorer for lav bentetthet (primær og sekundær) (NOF, 1998; European Commission, 1997; Workshop, 1997; Konsensusrapport, 1996; Seeman, 1997; Kanis et al., 1997; Salamone et al., 1999) - slik som lav vekt eller lav relativ vekt $\left(\right.$ BMI $=$ vekt/høyde ${ }^{2}$, laveste kvartil), vektreduksjon, lavt inntak av kalsium/D-vitamin, røyking, tidlig menopause, inaktivitet, høyt alkoholkonsum og genetiske faktorer. En amerikanske ekspertrapport understreker at lav kroppsvekt/ lav BMI er en av de sterkeste determinanter for lav bentetthet (NOF, 1998).

Studier kan tyde på at det er flere med lav relativ kroppsvekt i den norske befolkning sammenlignet med andre europeiske befolkninger - dobbelt så mange har BMI under 22 i Oslo sammenlignet andre deler av Europa (Falch og Meyer, 1998). Hos eldre synes lavt matinntak i seg selv å være en risikofaktor for lårhalsbrudd, men vi vet ikke om dette går gjennom lav bentetthet eller økt risiko for fall. Hos yngre er spiseforstyrrelser med etterfølgende tap av menstruasjon, en risikofaktor for osteoporose (Falch og Meyer, 1998;
Workshop, 1997), det samme er overtrening (Tomten et al., 1998).

Enkelte studier kan tyde på at høyt inntak av natrium, fosfat, protein, vitamin $\mathrm{K}$, vitamin $\mathrm{A}$ og koffein har sammenheng med lav bentetthet, og at bruk av thiazider, p-piller og C-vitamin henger sammen med høyere bentetthet, men ytterligere studier trenges før man kan konkludere (European Commission, 1997). Nylig publiserte dyrestudier har vist at inntak av grønnsaker - spesielt purre og ulike former for løk, reduserte tapet av benmasse betydelig hos hunnrotter (Mühlbauer og Li, 1999), det samme gjorde inntak av flere små måltider med adekvat kost, istedenfor ett stort (Li og Mühlbauer, 1999). Det gjenstår å se om menneskets stoffskifte reagerer på samme måte som rottenes.

\section{Barn og ungdom}

Det er viktig med adekvat kosthold og fysisk aktivitet under den betydelige mineralisering av ben som foregår i barne- og ungdomsalderen. Blant norske barn og ungdommer er det vist en positiv samvariasjon mellom kalsium, mettet fett, fiber og vitamin C - og BMD (Gunnes og Lehmann, 1995). En prospektiv studie viste at vektbærende fysisk aktivitet - spesielt sammen med høyt kalsiuminntak, hadde størst effekt på BMD særlig blant barn under 11 år (Gunnes og Lehmann, 1996). Foreløpig har vi ingen studier som viser om slike forebyggende tiltak har noen betydning for "peak bone mass" eller senere brudd (RCP, 1998).

\section{Menn}

Når det gjelder osteoporose blant menn vet vi mindre enn for kvinner, selv om opptil $30 \%$ av lårhalsbruddene skjer blant menn (Eastell et al., 1998). Vi kjenner ikke normalfordelingen av bentetthet og ekspertene er usikre på om man kan bruke tilsvarende definisjon på osteoporose som for kvinner. En ny britisk rapport anbefaler det (RCP, 1998). Det er også foreslått å bruke 1 SD under aldersjusterte gjennomsnitt som en indikator for terapi (Eastell et al., 1998). Mye tyder på at risikofaktorer som hypogonadisme, lav kroppsvekt, røyking, høyt alkoholinntak, inaktivitet, visse kroniske sykdommer og bruk av corticosteroider også er viktige risikofaktorer for lav bentetthet blant menn (Eastell et al., 1998).

\section{DIAGNOSTISERING}

\section{a) Bentetthetsmåling}

Måling av bentetthet kan brukes til 1) å stille diagnose og si noe om fremtidig risiko for brudd, 2) å følge opp et behandlingsregime eller 3) å overvåke utviklingen i bentetthet hos risikopersoner. Bentetthetsmåling i diagnostisk øyemed bør bare utføres dersom 1) målingen kan gi ytterligere informasjon om risiko for brudd, 2) det finnes en aktuell behandling som pasienten er villig til å forsøke, og 3) måleresultatet vil påvirke pasientens og/eller legens beslutning om forebyggende til- 
tak. Kan man ikke svare bekreftende på disse 3 punktene, bør man ikke måle (Søgaard og Berntsen, 1996).

Bentetthet er et mål på en knokkels mineralinnhold korrigert for knokkelens størrelse. Den vanligste målemetoden benytter absorpsjon av røntgenstråler (røntgen absorbsjonsmetri - SXA, DXA). Osteoporotiske pasienter taper benvev først og fremst i områder med mye trabekulært benvev, slik at måling av disse områdene (underarm, hofte, ryggvirvler, calcaneus) er de mest interessante i osteoporose-diagnostikk. Enkelte mener at èn enkelt måling av BMD ikke kan brukes til å stille diagnosen osteoporose (Sandor et al., 1999), men at man bør bruke lav bentetthet sammen med andre prediktive faktorer, slik som lav vekt, røyking, tidligere fraktur og fraktur hos nær slektning (Eastell, 1999) før man stiller en diagnose som får behandlingsmessige konsekvenser. På grunn av målefeil og problemer med målepresisjon, er det normalt ikke nødvendig å gjenta en måling før det har gått minst 2 år (Workshop, 1997).

\section{b) Biokjemiske markorer}

De mest vanlige biokjemiske markører er serumkonsentrasjon av benspesifikk alkalisk fosfatase og osteokalsin. Disse tester øker forutsigbarheten for brudd når de kombineres med bentetthetsmåing, men anbefales foreløpig ikke som diagnostisk hjelpemiddel, blant annet pga. store variasjoner fra dag til dag hos samme person (European Commission, 1997; Midtby og Magnus, 1998).

\section{FOREBYGGENDE TILTAK}

Enkelte studier tyder på at reduksjonen i frakturrate etter ulike tiltak - f.eks. HRT, overstiger de reduksjoner man skulle forvente basert på økning i bentetthet (Barrett-Connor, 1998). Dette betyr trolig at ulike forebyggende tiltak både virker gjennom effekt på bentetthet $o g$ gjennom effekt på balanse/falltendens/atferd. Ingen studier av ikke-medikamentell forebygging har hittil kunnet vise like store effekter på bentetthet eller frakturrate som man finner etter medikamentell intervensjon (Seeman, 1997).

\section{a) Screening}

Fordi en reduksjon $\mathrm{i}$ bentetthet korrelerer med økt risiko for brudd, ønsker mange å bruke måling av bentetthet som et hjelpemiddel for å kunne forutsi risikoen for senere brudd. Det viser seg imidlertid at langt fra alle med lav bentetthet får brudd, og langt fra alle brudd er et resultat av lav bentetthet (SBU, 1995). Dessuten tilsier problemer med presisjon og artefakter i forbindelse med målingene, at en enkelt måling gir dårlig prediksjon for senere brudd. Litteraturoversikter og meta-analyser konkluderer med at måling av BMD kan forutsi senere brudd, men ikke identifisere individer som vil få brudd (Hailey et al., 1998; Marshall et al., 1996). Generell screening kan også ha enkelte negative konsekvenser. Fordi måleinstrumentet ikke er godt nok til å skille friske fra syke, vil mange friske feilaktig få vite at de har høy risiko for brudd. Å få en slik beskjed vil kunne føre til angst og uro, og enkelte vil kanskje slutte med fysisk aktivitet av redsel for å falle. Generell bentetthetsmåling vil trolig føre til økt sykdomsfokusering, og muligheten for nedsatt total livskvalitet er til stede.

Man anbefaler derfor foreløpig ikke innført screeningprogram for postmenopausale kvinner (SBU, 1995; Konsensus-rapport, 1996; European Commission, 1997; NOF, 1998; RCP, 1998; SMM, 1999). Flere av disse anbefaler heller ikke screening av asymptomatiske høyrisikogrupper, mens andre mener man bør måle BMD på pasienter med tidligere lavtraume-frakturer eller ved tilstedeværelsen av sterke risikofaktorer ("case-finding") (RCP, 1998). En svensk ekspertgruppe anbefaler bare BMD-måling for pasienter med sykdom eller medikamentbruk som kan føre til lav bentetthet, og for monitorering av behandling (SBU, 1995).

Fordi generell screening foreløpig ikke anbefales, må personer med høy risiko for osteoporotiske brudd identifiseres ved hjelp av en kombinasjon av bentetthetsmåling, biomarkører og kliniske/anamnestiske risikofaktorer - som sykdommer, medikamenter, høyde, $\mathrm{BMI}$, livsstilsfaktorer, $\mathrm{Ca} / \mathrm{D}$-vitamininntak, tidligere brudd, brudd hos mor, sen menarche, tidlig menopause, svekket syn, falltendens osv (SLK, 1997; European Commission, 1997; Cummings et al., 1995; Johnell et al., 1995). De som tilhører høyrisikogruppen og som har lav bentetthet, bør få tilbud om bruddforebyggende tiltak tilpasset det enkelte individ.

\section{b) Ikke-medikamentelle tiltak}

\section{Fysisk aktivitet}

Fysisk aktivitet er viktig for vekst og remodellering av ben, og vektbærende fysisk aktivitet i barne- og ungdomsårene her vist sammenheng med høyere benmasse (Gunnes og Lehmann, 1996; European Commission, 1997). Høy grad av fysisk aktivitet før og under puberteten har større effekt enn senere. Det er trolig en additiv effekt av fysisk aktivitet og inntak av kalsium på "peak bone mass" (European Commission, 1997). Fullstendig immobilisering er assosiert med opp til $40 \%$ reduksjon i total benmasse, mens vektbærende fysisk aktivitet kan føre til økt knokkelspesifikk benmasse. Økningen i BMD som kan oppnåes gjennom fysisk aktivitet er imidlertid forholdsmessig liten, og taper seg raskt når aktiviteten opphører (European Commission, 1997; Fagerheim et al., 1998). Meget stor treningsintensitet/mengde kan føre til redusert benmasse og brudd - vesentlig pga. menstruasjonsforstyrrelser (European Commission, 1997; Workshop, 1997; Tomten, 1998).

Kontrollerte forsøk med fysisk aktivitet - og metaanalyser av slike, viser at treningsprogrammer, særlig med vektbærende belastning, forebygger eller reverserer bentap blant postmenopausale kvinner (Berard et al., 1997; Fagerheim et al., 1998; Kelly, 1998). Wolff 
et al. (1999) konkluderer i en meta-analyse av 25 randomiserte kliniske studier at fysisk aktivitet kan forebygge eller reversere ca. $1 \%$ av bentapet per år $\mathrm{i}$ ryggrad og lårben - både før og etter menopausen. Lengden på treningsøktene er trolig ikke utslagsgivende, derimot må benvevet utsettes for intense uvanlige drag, strekk og varierte belastninger (Fagerheim et al., 1998). Høy belastning, med få repetisjoner er bedre enn utholdenhetsregimer med lav belastning og mange repetisjoner (Kerr et al., 1996).

For utsatte grupper av postmenopausale kvinner med osteoporose - som også bruker $\mathrm{Ca} / \mathrm{D}$-vitamin, kan mindre krevende fysisk aktivitet - som daglige spaserturer og gymnastikk bidra til å redusere tapet og kanskje øke bentettheten i ryggraden. Man må imidlertid opprettholde aktiviteten for å holde på effekten. En meta-analyse av intervensjoner på fysisk aktivitet blant hjemmeboende eldre har vist at det er mulig å øke og opprettholde moderat fysisk aktivitet - spesielt hvis den er koblet til sosial hygge og glede (Province et al., 1995). En større litteraturgjennomgang konkluderer med at det er mulig å opprettholde fysisk aktivitet over lengre tid, hvis følgende forutsetninger er tilstede: grundig analyse av forutsetningene for å opprettholde aktiviteten, valg av aktiviter med vekt på realisme i intensitet, aktivitetene må integreres i personenes øvrige livsstil og dagligliv, at det legges opp til mange kontakter med deltakerne og at man sørger for støtte fra det sosiale miljøet (Laitakari et al., 1996).

\section{Røyking}

Røykere har lavere benmasse enn ikke-røykere (European Commission, 1997; Johnell et al., 1995), med eks-røykere i en mellomkategori. Etter 5 år har eksrøykere fremdeles høyere risiko for lårhalsbrudd enn aldri-røykere (Forsén et al., 1998). Røyking øker risikoen for lav BMD og lårhalsbrudd, spesielt blant postmenopausale kvinner og kvinner med lav/middels vekt (BMI<25) (Forsén et al., 1994), mens vekt ikke ser ut til å spille samme rolle for røykingens betydning for BMD blant menn (Law og Hackshaw, 1997). Livstidsrisikoen for lårhalsbrudd øker med $50 \%$ hvis man røyker (Law og Hackshaw, 1997). Det er umulig å gjennomføre randomiserte klinisk kontrollerte studier for å beregne effekten av røyking på BMD, men man kunne gjennomføre studier for å måle effekten av røykeslutt.

\section{Alkohol}

Bentettheten er redusert hos alkoholikere, men moderat alkoholinntak (2-3 glass vin per dag for kvinner) ser ut til å gi høyere BMD (European Commission, 1997), et funn som bekreftes av en positiv sammenheng mellom moderat alkoholinntak og lavere prevalens av vertebrale frakturer. Alkohol har imidlertid en negativ sammenheng med fall og andre ulykker. Det har ikke vært gjennomført klinisk kontrollerte studier mht. effekten av alkohol på bentetthet.

\section{c) Medikamentelle tiltak}

European Commission (1997) anbefaler bare bruk av kalsium/D-vitamin og HRT (Hormon Replacement Therapy) som primærforebygging ved osteoporose uten forutgående brudd.

\section{Østrogen}

Flere randomiserte kontrollerte studier viser at kvinner som tar hormonsubstitusjon (Hormon Replacement Therapy - HRT) bevarer eller øker benmassen og resultatene er like gode eller bedre for kombinasjonsbehandling med østrogen/progesteron (Barrett-Connor, 1998). HRT og bisfosfonater (Berntsen et al., 1997), HRT og mosjon (Berntsen et al., 1997), HRT og kalsium (Berntsen et al., 1997; Barrett-Connor, 1998), samt HRT og D-vitamin (Tuppurainen et al., 1998) ser alle ut til å være mer effektive enn HRT alene når det gjelder bentetthet. Selv om HRT er effektiv med hensyn til å bevare benmasse, synes det som effekten reduseres relativt raskt når man slutter å bruke medikamentet (Hailey et al., 1998). Ti år etter avsluttet behandling var bentetthet og frakturrisiko lik hos kvinner som hadde tatt østrogen og de som ikke hadde brukt HRT (Barrett-Connor, 1998).

\section{Kalsium og D-vitamin}

Det er en positiv sammenheng mellom kalsium/Dvitamin og bentetthet i ulike aldersgrupper (European Commission, 1997). Eldre utskiller mer kalsium og absorberer mindre, bl.a. pga. lav tilførsel av D-vitamin fra kost og sollys, noe som tilsier at mange eldre bør ta ekstra kalsium og D-vitamin. En eksperimentell studie har gitt betydelig økning i bentetthet (og reduksjon i lårhalsbrudd) med ekstra tilførsel av $1200 \mathrm{mg} \mathrm{Ca} \mathrm{og}$ 800 IE D-vitamin til eldre på sykehjem (Chapuy et al., 1994), mens noe lavere doser gitt til hjemmeboende eldre ga effekt på bentetthet, men effekten avtok etter det første året (Dawson-Hughes et al., 1997). Effekten av tilskudd i denne størrelsesorden støttes av en ny norsk sammendragsrapport (SMM, 1999), og gjør det åpenbart nødvendig med en samordning og oppdatering av ulike norske anbefalinger: a) norske næringsstoffanbefalinger anbefaler $800 \mathrm{mg} \mathrm{Ca}$ og 400 IU Dvitamin per dag) (Norske næringsstoffanbefalinger, 1997), b) nordiske terapianbefalinger mht. osteoporose anbefaler 500-1000 mg Ca og 400-800 IE D-vitamin per dag (SLK, 1997). Personer som bruker corticosteroider bør bruke kalsium/D-vitaminer profylaktisk (Homik et al., 1998). I dag bruker under 10\% av disse pasientene slik terapi.

\section{Bare kalsium}

Studier som bare gir kalsium viser også gjennomgående positiv effekt på bentetthet, og flere oversiktsartikler/meta-analyser støtter den rådende anbefaling om ekstra kalsiumtilførsel til eldre kvinner, spesielt til kvinner med tidligere frakturer og lavt inntak av kalsium gjennom kosten (European Commission, 1997). Flere studier tyder på at man må ha et relativt høyt 
daglig inntak av kalsium for å få positiv effekt på bentettheten (European Commission, 1997) - tilskudd på 1000-1500 mg eller et totalt daglig inntak på 1650$1990 \mathrm{mg} /$ dag. Dersom Ca-inntaket er adekvat $(>800$ $\mathrm{mg}$ ) finner man en positiv sammenheng mellom vitamin $\mathrm{C}$ og BMD, mens man ved lavere Ca-inntak finner en negativ virkning av koffein på bentettheten (Barrett-Connor et al., 1994).

\section{Bare D-vitamin}

Når D-vitaminer tas alene er litteraturen ikke konklusiv (Gillespie et al., 1998), men flere studier tyder på at mange eldre lider av D-vitamin mangel - spesielt eldre på institusjon (Mowe et al., 1998). Måling av Dvitamin $(25 \mathrm{OHD})$ i serum viser at de med høyt nivå også har høy BMD (Khaw et al., 1992).

\section{BEHANDLINGSMULIGHETER}

Flere senere oversiktsartikler, konsensuskonferanser og ekspert-rapporter drøfter behandling av osteoporose (Workshop, 1997; Seeman, 1997; Kanis et al., 1997; European Commission, 1997; NOF, 1998; RCP, 1998; SMM, 1999). Ved etablert osteoporose (minst en fraktur og bentetthet under 2,5 SD) anbefales i Norden kalsium/D-vitamin som basisbehandling til alle, og som eneste behandling til de aller eldste av begge kjønn (SLK, 1997). For kvinner under 70 år er førstevalget HRT, mens bisfosfonat (aledronate og etidronat) anbefales de øvrige. Testosteron er førstevalg for menn med etablert osteoporose, unntatt ikkehypogodale menn som anbefales bisfosfonat (SLK, 1997). I løpet av det siste året er det kommet nye medikamenter på markedet i Norge: raloxifen (selektiv østrogen reseptor modulator $=$ SERM), tibolon (et syntetisk steroid med blandet østrogen, progestogen og androgen effekt) og HRT i lavere doser enn tidligere. Calcitonin, som har vist god effekt på BMD, men mindre dokumentert effekt på brudd, har i tillegg en analgestisk effekt. Fluorid anbefales ikke brukt i vanlig osteoporosebehandling. Mange nye medikamenter vil trolig komme på markedet $\mathrm{i}$ tiden fremover: ipriflavon/isoflavon - ikke-steroide plantederivater (hovedsakelig soyaprodukter) med østrogenlignende effekter, vitamin D-metabolitter, paratyreoid hormon, veksthormon/anabole stereoider, samt nyere generasjoner av bisfosfonater (f.eks. risedronate), og andre typer SERM. Også ulike kombinasjonsregimer av forskjellige medikamenter - og kombinasjoner av medikamenter og fysisk aktivitet er under utprøving.

\section{SLUTTKOMMENTAR}

Forebygging av lårhalsbrudd, som er den alvorlige konsekvens av lav bentetthet, kan gjøres gjennom forebygging av lav bentetthet, forebygging av fall og/eller å dempe kraften på hoften når man faller (f.eks. hoftebeskyttere). Denne oversikten har i hovedsak sett på den ene av disse komponentene - nemlig lav bentetthet, samt drøftet WHOs definisjon av osteoporose som er forbundet med enkelte problemer: a) Osteoporose er både en risikofaktor for brudd - og en betegnelse på en tilstand som forutsetter minst ett brudd (etablert osteoporose). Denne "dobbeltrollen" fører lett til sammenblanding og forvirring når man drøfter diagnose, utbredelse, risikofaktorer, forebyggende tiltak og behandling (SMM, 1999; RCP, 1998, Europeen Commision, 1998) - og i diskusjoner om osteoporose med politikere og i media.

b) Bruker vi WHOs definisjon for osteoporose vil ca. $70 \%$ av kvinnene over 70 år ha en slik diagnose. Dette medfører en dramatisk medikalisering av den eldre kvinnelige befolkning. Fordi lav bentetthet bare er en av flere risikofaktorer for brudd, og prediksjonen er relativt lav, vil man risikere å plukke ut mange personer som aldri vil få brudd. Å få diagnosen osteoporose (= syk) vil kunne føre til psykologiske og atferdsmessige bivirkninger, slik som angst og lavere fysisk aktivitet av redsel for å falle. I tillegg vil personer som har fått "merkelappen" osteoporose, trolig gå oftere til legen for nye kontroller med nye BMD-målinger, og mange av dem vil bruke medisiner på blåresept. Det er vist at 91 kvinner må behandles i gjennomsnitt 2,9 år for å forebygge ett lårhalsbrudd blant kvinner med minst ett brudd fra før (Hetlevik og Grimstad, 1997).

c) Osteoporose er asymptomatisk før man har fått noe brudd, og har ingen automatiske behandlingsmessige konsekvenser. Man kan imidlertid frykte at WHOs definisjon også vil tvinge frem krav om medikamentell forebyggende behandling utover det som i dag anbefales. På grunn av det økende krav om at alle råd skal verifiseres med randomiserte klinisk kontrollerte fors $ø$, har den engelske osteoporose-ekspertgruppen (RCP, 1998) ikke kunnet gi noe råd om ikkemedikamentelle forebyggende tiltak mot osteoporose. Dette til tross for at det finnes god dokumentasjon mht. forebyggende effekter av både fysisk aktivitet og $\mathrm{Ca} / \mathrm{D}$-vitamin på bentetthet. Samlet vil WHOs definisjon, legemiddelindustriens sterke markedsføring og kravene til hva som er "riktig" kunnskap, kunne underminere mulighetene for å anbefale ikkemedikamentelle forebyggende tiltak.

d) Vi mangler studier som viser WHO-definisjonens spesifisitet og sensitivitet mht. senere brudd. Men fordi vi vet at det er stor overlapping i bentetthet mellom dem som får lårhalsbrudd og dem som ikke får slike brudd, vil trolig WHOs definisjon ha lav spesifisitet (GKR Berntsen, personlig kommentar). Fremtidig strategi mht. identifisering av høyrisikoindivider må være å kombinere mål for bentetthet med andre etablerte risikofaktorer for lårhalsbrudd (NOF, 1998; Eastell, 1999).

Det er trolig riktigere i fremtiden å betrakte osteoporose som en viktig risikofaktor for brudd, slik høyt serumkolesterol er en risikofaktor for hjerteinfarkt. WHOs diagnose bør derfor endres - og forbeholdes personer med BMD mellom 1 SD og 2,5 SD under maksimal bentetthet hos unge kvinner. Definisjon av osteoporose for menn må utredes nærmere. 


\section{REFERANSER}

Abrahamsen B, Hansen TB, Jensen LB, Hermann AP, Eiken P. Site of osteodensitometry in perimenopausal women: correlation and limits of agreement between anatomic regions. J Bone Miner Res 1997; 12: 1471-9.

Barrett-Connor E. Hormone replacement therapy. Fortnightly review. BMJ 1998; 317: 457-61.

Barrett-Connor E, Chang JC, Edelstein SL. Coffee-associated osteoporosis offset by daily milk consumption. The Rancho Bernardo Study. JAMA 1994; 271: 280-3.

Berard A, Bravo G, Gauthier P. Meta-analysis of the effectiveness of physical activity for the prevention of bone loss in postmenopausal women. Osteoporos Int 1997; 7: 331-7.

Berntsen GKR, Søgaard AJ, Fønnebø B, Joakimsen RM, Tollan A, Magnus JH. Distribution of bone mineral density in a normal population. Initial results from TROST (Tromsø Osteoporosis Study). Osteoporos Int 1996; 6 (Suppl 1): 123.

Berntsen GKR, Tollan A, Fønnebø V. Postmenopausal hormonsubstitusjon - for de mange eller for de få? Del I. Effekter av langtids hormonsubstitusjon. Nord Med 1997; 112 (8): 276-9, rettelse 330.

Chapuy MC, Arlot ME, Delmas PD, Meunier PJ. Effect of calcium and cholecalciferol treatment for three years on hip fractures in elderly women. BMJ 1994; 308: 1081-2.

Cauley JA, Lucas FL, Kuller LH, Vogt MT, Browner WS, Cummings SR. Bone mineral density and risk of breast cancer in older women: the study of osteoporotic fractures. Study of Osteoporotic Fractures Research Group. JAMA 1996; 276: 1404-8.

Cummings SR, Nevitt MC, Browner W, Stone K, Fox KM, Ensrud KE, et al. for the Study of Osteoporotic Fractures Research Group. Risk factors for hip fractures in white women. N Engl J Med 1995; 332: 767-73.

Dawson-Hughes B, Harris SS, Krall EA, Dallal GE. Effect of calcium and vitamin D supplementation on bone density in men and women 65 years of age or older. N Engl J Med 1997; 337: 670-6.

Eastell R. Commentary: bone density can be used to assess fracture risk. BMJ 1999; 318: 864-5.

Eastell R, Boyle IT, Compston J, Cooper C, Fogelman I, Francis RM, et al. Management of male osteoporosis: report of the UK Consensus Group. $Q J$ Med 1998; 91: 71-92.

European Commission. Report on osteoporosis in the European Communitiy - Action for prevention. Employment and social affairs. Brussel: European Communities 1997.

Fagerheim E, Gjellestad K, Næss E. Kan fysisk aktivitet redusere tap av benmasse hos postmenopausale kvinner? En oversiktsartikkel. Eksamensoppgave ved Videreutdanning i fysioterapi. Oslo: Statens institutt for folkehelse, 1998.

Falch JA, Meyer HE. Osteoporose og brudd i Norge. Forekomst og risikofaktorer. Tidsskr Nor Lageforen 1998; 118: $568-72$.

Forsén L, Bjørndal A, Bjartveit K, Edna TH, Holmen J, Jessen V, Westberg G. Interaction between current smoking, leanness, and physical inactivity in the prediction of hip fracture. J Bone Miner Res 1994; 9: 1671-8.

Forsén L, Bjartveit K, Bjørndal A, Edna TH, Meyer HE, Schei B. Ex-smokers and risk of hip fracture. Am J Public Health 1998; 88: 1481-3.

Gillespie WJ, Henry DA, O'Connell DL, Robertson J. Vitamin D and vitamin D analogues for preventing fractures associated with involutional and post-menopausal osteoporosis (Cochrane Review). In: The Cochrane Library, Issue 3, 1999. Oxford: Update Software.

Gunnes M, Lehmann EH. Dietary calcium, saturated fat, fiber and vitamin C as predictors of forearm cortical and trabecular bone mineral density in healthy children and adolescents. Acta Paediatr 1995; 84: 388-92.

Gunnes M, Lehmann EH. Physical activity and dietary constituents as predictors of forearm cortical and trabecular bone gain in healthy children and adolescents: a prospective study. Acta Paediatr 1996; 85: 19-25.

Hailey D, Sampietro-Colom L, Marshall D, Rico R, Granados A, Asua J. The effectiveness of bone density measurement and associated treatments for prevention of fractures. An international collaborative review. Int Technol Assess Health Care 1998; 14: 237-54.

Hetlevik I, Grimstad H. Forebygging av risiko. Riktig informasjon kan villede. Tidsskr Nor Laegeforen 1997; 117: $1170-1$.

Høiseth A. Osteoporose. Benmasse, brudd, behandling og etterlevelse. Tidsskr Nor Lageforen 1997; 117: 3188-90.

Homik J, Suarez-Almazor ME, Shea B, Cranney A, Wells G, Tugwell P. Osteoporosis (OP): Calcium (Ca) and Vitamin D for the treatment of corticosteroid-induced osteoporosis (Cochran Review). In: The Cochran Library, Issue 4, 1998. Oxford: Update Software.

Johansson C, Black D, Johnell O, Oden A, Mellstrom D. Bone mineral density is predictor of survival. Calcif Tissue Int 1998; 63: 190-6.

Johnell O, Gullberg B, Kanis JA, Allander E, Ellfors L, Dequerker J, et al. Risk factors for hip fracture in European women: The MEDOS Study. J Bone Miner Res 1995; 10: 1802-15.

Kanis JA, Delmas P, Burckhardt P, Cooper C, Torgerson D. Guidelines for diagnosis and management of osteoporosis. The European Foundation for Osteoporosis and Bone Disease. Osteoporos Int 1997; 7: 390-406. 
Kelley GA. Exercise and regional bone mineral density in postmenopausal women: a meta-analytic review of randomized trials. Am J Phys Med Rehabil 1998; 77: 76-87.

Kerr D, Morton A, Dick I, Prince R. Exercise effects on bone mass in postmenopausal women are site-specific and load-dependent. J Bone Miner Res 1996; 11: 218-25.

Khaw KT, Sneyd MJ, Compston J. Bone density parathyroid hormone and 25-hydroxyvitamin D concentrations in middle aged women. BMJ 1992; 305: 273-7.

Konsensus-rapport. Osteoporose (Benskjørhet). Oslo: Norsk Osteoporoseforening, Statens helsetilsyn, Norske Kvinners Sanitetsforening, 1996.

Laitakari J, Vuori I, Oja P. Is long-term maintenance of health-related physical activity possible? An analysis of concepts and evidence. Health Educ Res 1996; 11: 463-77.

Law MR, Hackshaw AK. Meta-analysis of cigarette smoking, bone mineral density and risk of hip fracture: recognition of a major effect. BMJ 1997; 315: 841-6.

Li F, Mühlbauer RC. Food fractionation is a powerful tool to increase bone mass in growing rats and to decrease bone loss in aged rats: modulation of the effect by dietary phosphate. J Bone Miner Res 1999; 14: 1457-65.

Marshall D, Johnell O, Wedel H. Meta-analysis of how well measures of bone density predict occurrence of osteoporotic fractures. BMJ 1996; 312: 1254-9.

Midtby M, Magnus JH. Kan biokjemiske markører for benomsetning anbefales som diagnostisk og prognostisk verktøy ved osteoporose? Tidsskr Nor Lageforen 1998; 118: 575-9.

Mowe M, Bøhmer T, Haug E. Vitamin D-mangel hos eldre sykehusinnlagte og hjemmeboende i Oslo. Tidsskr Nor Lageforen 1998; 118: 3929-31.

Mühlbauer RC, Li F. Effect of vegetables on bone metabolism. Nature 1999; 401: 343-4.

NOF. National Osteoporosis Foundation. Osteoporosis: review of the evidence for prevention, diagnosis and treatment and cost-effectiveness analysis. Status report. Osteoporos Int 1998; 8 (Suppl 4): S7-80.

Norske næringsstoffanbefalinger 1997. Oslo: Statens ernæringsråd, 1997.

Province MA, Hadley EC, Hornbrook MC, Lipsitz LA, Miller JP, Mulrow CD, et al. The effects of exercise on falls in elderly patients. A preplanned meta-analysis of the FICSIT Trials. Frailty and Injuries: Cooperative Studies of Intervention Techniques. JAMA 1995; 273: 1341-7.

RCP. Royal College of Physicians. Osteoporosis: Clinical guidelines for prevention and treatment. London, UK: Department of Health, 1998.

Salamone LM, Cauley JA, Black DM, Simkin-Silverman L, Lang W, Gregg E, et al. Effect of a lifestyle intervention on bone mineral density in premenopausal women: a randomized trial. Am J Clin Nutr 1999; 70: 97-103.

Sandor T, Felsenberg D, Brown E. Comments on the hypotheses underlying fracture risk assessment in osteoporosis as proposed by the World Health Organization. Calcif Tissue Int 1999; 64: 267-70.

SBU. Statens beredning för utvärdering av medicinsk metodik. Mätning av bentäthet. SBU-rapport nr 127. Stockholm: Statens beredning för utvärdering av medicinsk metodik, 1995.

Seeman E (ed). Advances in the epidemiology, prevention, and treatment of osteoporosis and fractures. Am J Med 1997: 103 (2A): 1S-92S.

SMM. Senter for medisinsk metodevurdering. Diagnostikk, forebyggelse og behandling av osteoporose. En oppsummering av internasjonale utredninger. SMM-rapport nr. 4/1999. Oslo: Senter for medisinsk metodevurdering, SINTEF Unimed, 1999.

SLK. Statens legemiddelkontroll. Terapianbefalinger: Behandling av osteoporose. Nytt om legemidler 1997; 20 (Suppl 1): 1-23.

Søgaard AJ, Berntsen GKR. Bør vi måle bentetthet på alle? Tidskr Nor Logeforen 1996; 116: 2297-8.

Tomten SE, Falch JA, Birkeland KI, Hemmersbach P, Høstmark AT. Bone mineral density and menstrual irregularities. A comparative study on cortical and trabecular bone structures in runners with alleged normal eating behavior. Int J Sports Med 1998; 19: 92-7.

Tuppurainen MT, Komulainen M, Kroger H, Honkanen R, Jurvelin J, Puntila E, et al. Does vitamin D strengthen the increase in femoral neck BMD in osteoporotic women treated with estrogen? Osteoporos Int 1998; 8: $32-8$.

WHO Study Group. Assessement of fracture risk and its application to screening for postmenopausal osteoporosis. Geneva: WHO Technical Report Series, No. 843, 1994.

Wolff I, van Croonenborg JJ, Kemper HC, Kostense PJ, Twisk JW. The effect of exercise training programs on bone mass: a meta-analysis of published controlled trials in pre- and postmenopausal women. Osteoporos Int 1999; 9: 1-12.

Workshop. Treatment of osteoporosis. The Norwegian Medicines Control Authority and Medical Products Agency, Sweden. Oslo, Norway: Statens Legemiddelkontroll, 1997; 2: 1-220. 